\title{
Gender policy disjunction in education in Kenya: Silence, spaces and the implications of vacuum
}

\section{Chris Yates}

Institute of Education

University of London 


\section{Gender policy disjunction in education in Kenya: Silence, spaces and the implications of vacuum}

- To make globalization work there will have to be a change of mindset: we will have to think and act more globally. Today, too few have this sense of global identity (Stiglitz 2006, 278279).

- ...what we are dealing with ... is a triple entanglement: of fact, convention and value'. The role that an understanding of conventions plays in making sense of our social and ethical inquiries is particularly worth emphasizing...(Sen 2009:119)

- I think they have to now open up and accept some support from other IP's. They cannot work in isolation and achieve everything because there could be a vacuum ... There is no way they can work in isolation because it is like you want to operate in a vacuum (Kenya Ministry of Education Respondent 2008). 


\section{The Power Cube}

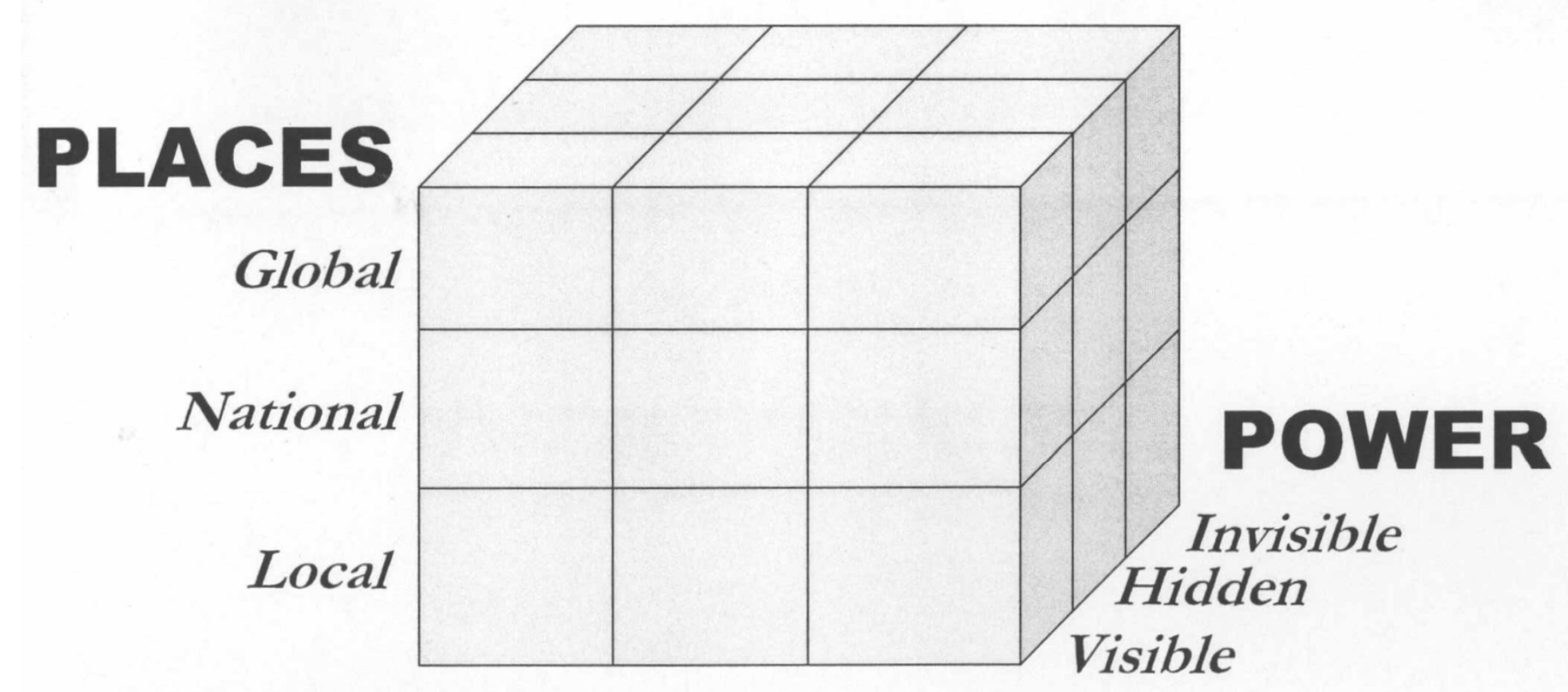
Closed/
Invited
Claimed/
uninvited
created
SPACES 


$$
\begin{aligned}
& \text { A thought } \\
& \text { experiment }
\end{aligned}
$$




\section{Forms of disconnection in the gender-education-poverty nexus}

- Vertical disconnection;

- Horizontal disconnection;

- Distancing;

-Normalisation. 


\section{Vertical disjuncture: National control}

(closure) versus Cosmopolitan openness (interference)

- How did you enter the Ministry? ... My problem was not with your entry but my problem was going to be how do you disseminate the results if you did not enter properly because for them to be consumed the best person could be the executive of the Ministry who is the PS, but we can moderate them before they get to the PS, so there should be no problem. (MoE Respondent 2008) 


\section{Vertical disjuncture: National control}

(closure) versus Cosmopolitan openness

\section{(interference)}

- the ultimate units of moral concern are individual human beings not states or other particular forms of human association. Humankind belongs to a single moral realm in which each person is equally worthy of respect and consideration. To think of people as having equal moral value is to make a general claim about the basic units of the world comprising persons as free and equal beings. This notion can be referred to as the principle of individualist moral egalitarianism or, simply, egalitarian individualism (Held 2005: 12). 


\section{Silent spaces}




\section{Vertical closure: What gets lost in translation - policy hiatus and attenuation?}

-What we have realised is that the gender policy (alone) is not good enough so we are developing guidelines to help people at different levels on how to implement the policy (emphasis added) 
- The entry point is very important. You need to do it gradually and make them understand and make them be part of the program because like now what I have realised after learning when I want to initiate a program, I go on the ground, I discuss it with them and I plan with them. And in fact they are the ones who give me the ideas what are their priorities instead of it being from me. It should be bottom up not up bottom and that way it works, then ownership they own the program. But when you don't involve them directly from the grass root then if the project is for five years then after five years it is done, nothing. 


\section{Horizontal closure: Displacement and deferment - closure of potential newly created spaces (distancing)}

- You see the Ministry has a gender desk that addresses wider issues... you see l'm only talking about within $(X X)$ perspective ... The ministry has a gender desk and there are those issues we're dealing on gender issues in education, manpower affirmative action the ministry is having, but l'd like them to be addressed by the actual people concerned because the ministry has a person dealing with gender... 


\section{Blurred accountability}

- We develop policies and launch them among ourselves as the education stakeholders. But the public doesn't know of the existence of the policy or their role. ... how can we engage the public so that they hold schools and education officials accountable. So there's need for us to engage the public; because they are our eyes and ears on the ground... And everybody has his or her role to play, not just me as an education official, everybody has a role to play. So there is a need form us first of all to find out what the gaps are and ways of addressing those gaps. And let the public know that they are also stakeholders in education. It is not somebody out there to come and say, they too can hold the head teacher to account. (MoE respondent May 2008) 


\section{Architectural determinism, gender inequality and sensitive interconnection: An example of normalisation?}

- Now again for the girls who have reached puberty those facilities (pit latrines) are not friendly, she wants to go and change her sanitary towels. She fears she uses it the blood will drop on toppeople will laugh at he, so she would rather not - she would rather go to the bush, or she would rather stay at home until when she is through with her periods. This is what is happening in many areas, girls are not going to school five days in a month and when you count five days a month times twelve months, and those are actually two months, they have missed of learning in schools so this two months times five or six years. What you are talking about, a year is going that she missed - so what does it translate to, then we say girls are thick headed, poor performance. They are the basic things we are not thinking of but yet they have got a lot of implication on education 


\section{New spaces for improved understanding and agency}

- When it comes to gender it is worse for the learner with special needs. Girls with special needs suffer the most especially in schools that have no special units. And now when you look at the mentally challenged they don't even know what is happening, whether they are abused or not and you get most of them are infected... 
- If it could be taken seriously by senior management now it could be very easy, flowing down. If they were part of it would be very easy. If now the senior managers are not taking it seriously then what about 'watu wa mkuno' (junior people) will they take it seriously? We need to understand gender very well. The hindrance is also where we are coming from, that is the social cultural background so senior managers should go beyond social cultural barriers. Gender problem has emanated from the socialization processes we passed through. Like the government should spearhead this, like now the affirmative action has not been taken very seriously It was worse during Moi's time like one day he mentioned 'wnanamke kiti gani' (What is a women?) in a public. So he meant that a woman is like a child. And this is brought about by the way we are socialised. 


\section{Loose-tight policy framing and national service delivery}

- ... we look at the curriculum as an integrated one we give them treatment and of course the education and sanitation facilities and then there must be a policy because we can't do this in a vacuum. We must have a policy framework to support these activities. So that you might one NGO might come or one donor like UNICEF, they are only able to put up water tanks and toilets. They are not giving the education so it means somebody else has to give that education. Somebody else has to print the materials. It is a joined effort. ...

We have a policy framework to guide us. We have the ECD policy and we also have the school health and nutrition policy which is in the draft form... but we are using it because the principles don't change the issues we are addressing. 
THANK YOU 